\title{
Why Muhammad?
}

\section{Murad Wilfried Hofmann}

God's reasoning is unfathomable. Nevertheless, not only orientalists but Muslims are well-advised to ponder on occasion questions linked to the Night of Destiny (laylat al qadr): Why, of all people, was Muhammad, a person who lived in Arabia, of all places, and in the seventh century C.E., chosen to deliver God's final message in Arabic, a heretofore obscure language in the larger world of that time? In our quest for answers to such questions, human reasoning may provide the following answers:

1) Seventh-century Arabia could not be reached by the power projection of the region's two dominant hegemonical states. The Christian (east) Roman empire of Heraclius I and the Iranian empire of the Sasanian Shah Chosraw II Parwez were completely absorbed in an ongoing struggle that would ultimately turn out to be fatal for both of them. The dualist Persian religions of Mithraism and Manichaeism had been consolidated into the official state religion of Zoroastrianism. Both empires would not have tolerated a new religion that, like Islam, could have shaken their very foundations. Only in the far distant and obscure land of Arabia could a new ideological state-community arise and consolidate itself before either of the two neighboring superpowers had a chance to intervene.

2) Arabia enjoyed a central geostrategic position with regard to the known world at that time, being at a similar distance from Morocco and China as well as England and Japan. Muslim expansion was greatly facilitated by the fact that in geographical terms, Islam was never marginal.

3) At that point in time, the languages of commerce and intellectual discourse-Latin, Greek, Persian, and Hebrew-had become so linked and interwoven as media for the transportation and interpretation of previous divine relations that they were now unsuitable for the new Islamic message. In order to bring about a theological revolution, particularly in the Christianized world, the Qur'anic message required a virginal language. We see how true this assessment is when we consult a translation of the Qur'an made by Christian orientalists. Whenever they encounter terms like al kalimat, al amr, or al rūh (al quddūs) they 
inevitably link them with such Christian concepts as Logos, Demiurge, or Holy Spirit.

4) The Arabic dialect spoken by the Quraysh had developed to such a level that it could transmit any verbalized message, no matter how abstract the idea.

5) Finally, the timing of the Qur'anic revelation made eminent sense. In the fifth century C.E., it had become evident that neither the Christians nor the Jews, by then dispersed all over the world, would be capable by themselves of correcting their own misinterpretations of the Old Testament and the Gospels.

Since Justinian I, Caesaropapism had become the totalitarian form of government of Byzantium. Both Roman law (corpus juris civilis) and Christian dogma had been codified, the former in 534 C.E. As regards the latter, the first ecumenical Council of Nicea (432 C.E.) adopted the Nicene creed, according to which the nature of Jesus (engendered and not created) was defined as being cosubstantial with God-Father: "true man and true God." For centuries to come, it was unthinkable to abolish this fatal dogma. On the contrary, the Church had to face even more extreme Christological theories, such as those of the Nestorians, who accorded Jesus only one divine nature. The Third Council, held in Ephesus during 431 C.E., and even the Fifth Council, held in Constantinople during 553 C.E., still had to deal with this Monophysitism.

Under these depressing circumstances, efforts to restore the common Abrahamic tradition of pristine monotheism could not be expected from within the Christian world. Such an endeavor had to be launched from the outside-from Arabia - and by a prophet who was charged with the sole mission of restoring (not innovating) Islam, the original religion of God, which according to Qur'an 46:9 is Islam.

\section{What is Left of the Nicene Creed?}

It is now 1,572 solar years since the Council of Nicea, chaired by a non-Christian emperor, ordered the majority of Christians-Arians and Christian Jews - to conceive of Jesus as the Son of God in the strictest sense of the term. Much time and effort has been spent since by both Catholic and Protestant theologians and philosophers in their ongoing attempt to understand and explain the resulting dogma of the divine incarnation in Jesus and the consequential construct of a divine trinity. They invariably failed-how could it be otherwise? - and therefore resorted to the supposedly unassailable argument that incarnation and trinity were divine mysteries. However, they failed to point out that Christians would 
only be entitled to consider this dogma a mystery if there were at least a slight basis for it in an authentic saying of Jesus. And this is, of course, not the case. Indeed, these "mysteries" gained currency only through a minority decision, which was supported by Emperor Constantine and his family clique for political reasons and pushed through at Nicea.

As for the Muslims, they remained undisturbed and held on to their own Christology as set out with great precision and clarity in the Qur'an. This can be summed up as believing that Jesus a) was created (not engendered) like Adam $(3: 47,59 ; 23: 91 ; 112: 3)$; b) was born of a virgin $(3: 47)$; c) confirmed the divine messages received before him (3:50); d) was a prophet like those before him $(2: 136 ; 3: 84 ; 6: 85)$; and e) was not one of the three divine persons within a multiple deity $(4: 171 ; 5: 73)$. Even socalled modernist and "cultural" Muslims have never challenged this Islamic concept of Jesus.

During the last two hundred years, it has also dawned on the Christian world that the belief that "God has taken unto Himself a son" (Qur'an 18:4-5; 19:88-89) is untenable. Indeed, the official dogmatic view of Jesus has experienced a glaring loss of credibility, which largely explains the spread of atheism and agnosticism during that period and the ever-growing rejection of established churches by people taking refuge in esoteric faiths: from anthroposophy and feminist theology to Buddhism and Native American Shamanism. Therefore, it was only natural that the last sixty years have seen bold attempts to reinterpret the status of Jesus within Christian orthodoxy. Such Protestant thinkers as Karl Barth (d. 1968), Rudolf Bultmann (d. 1976), and the Jesuit professor Karl Rahner were pioneers on this road.

Barth considered Jesus as "only" a human being chosen by God for his mission, a formidable status indeed. With his historical-critical method, Bultmann demythologized the New Testament to such an extent that most theologians now agree that it is impossible to reconstruct the historical Jesus, for the New Testament simply does not provide a sufficient foundation for this undertaking.

Rahner, in turn, engaged in intellectual acrobatics in order to reconcile his childhood faith with attempts to undo the Council of Nicea. On the one hand, he was courageous enough, in his Probleme der Christologie heute, to reshape the incarnation theory by stating that Jesus essentially was a human being characterized by total submission to God. According to him, divine incarnation in the sense of inspiration was a theoretical possibility open to everybody, and Jesus was a uniquely perfect example of such divine intervention. On the other had, he also formulated the blasphemy that God, after all, could countenance the possibility of a co-deity.

This may be enough to demonstrate that Christian Christology is in deep crisis. Such a predicament is mentioned in Qur'an 42:14: "As it is, behold, they who have inherited the divine writ from those who preceded 
them are (now) in grave doubt, amounting to suspicion, about what it portends" (translation Muhammad Asad).

Contemporary Catholic and Protestant theologians alike are trying to keep afloat by dumping overboard, a bit belatedly, as much as possible. Thus, within the Christian camp one can discern today the following three positions on Christology: a) Jesus was not a historical phenomenon; b) Jesus was a model man who was inspired and chosen by God, but was neither cosubstantial with Him nor ascended to heaven from his grave (Gerd Lüdemann); and c) virtues and vices are equally spread among the followers of all religions, which represent valid perspectives on the same reality (Paul Schwarzenau and John Hick).

The first trend led to the mystical construction of a "cosmological Jesus." The former Dominican monk Matthew Fox is toiling for the adoption of this new paradigm, as if his construction could be viable without a historical Jesus at its base. He seems to say that the idea of Jesus is so beautiful that one should invent him if he did not exist. Hick is right in pointing out that such a suprahistorical figure of Jesus is little else but another term for transcendental reality.

The second trend runs into the difficulty that such a Jesus can hardly claim a privileged position over other apostles and prophets. Indeed, their Messiah, is he not the Jesus of the Qur'an? This dilemma explains why some Christian thinkers now replace the defunct exclusive Catholic dogma (extra ecclesiam nulla salus/no salvation outside the church) with a new inclusive one that teaches that Jesus brought salvation to everybody. (This neatly turns all Muslims into so-called "anonymous Christians" . . . Thanks.) There is a grain of salt even in this construction: against the background of the dismantling of Jesus and his mother in the Christian world, we can conclude that in today's world only Muslims uphold the historical veracity and elevated status of both of them.

The third trend mentioned above aims at nothing less than the ecumenical unity of all religions, for which our "post-Christian era" is seen to be ripe.

The perspectives of this corrective process are breathtaking. For the first time in 1,400 lunar years, there is a very real chance that the Christian world will adopt the Jewish, Christian, and Qur'anic image of Jesus. If this should happen, the Islamic religion would have fulfilled its task in this important domain and the Christian-Jewish-Muslim trialogue could hope, for the first time, to advance dogmatically as well. Contrary to what Hans Küng has been suggesting, the status of Jesus would no longer be taboo and, as a direct result, nonnegotiable.

Alas, we have little reason to hope that we will now see Christians enter God's religion in hosts (Qur'an 110:2). It is more likely that the imminent collapse of established Christian churches will increase the demand in our multireligious supermarkets. Alienated from mainline churches, many of their highly emancipated and individualistic mem- 
bers may be expected not to embrace Islam but to make their own desires their deity (Qur'an 45:23). In short, despite the momentous developments within Christendom, Islam in the United States and Europe will most likely have to face the very mixture of attitudes so typical in Makkah at the time of the Prophet: neoheathens, agnostics, atheists, and neopolytheists, i.e., people who worship such idols as cocaine, astronomy, or Claudia Schiffer. But also in this respect, God knows best and to Him shall we all return. 